\title{
Peningkatan Kreatifitas Dan Minat Belajar Siswa Pada Mata Pelajaran Bahasa Inggris Dengan Menggunakan Cerita Rakyat Bima
}

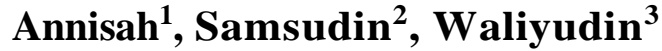 \\ STKIP Taman Siswa Bima \\ $\underline{\text { Annisahnukman@gmail.com }}{ }^{1}, \underline{\text { samsudinspdmor@gmail.com }}{ }^{2}$, waliyudinkhalik@gmail.com $^{3}$
}

\begin{abstract}
Abstrak . Tujuan penelitian ini adalah untuk meningkatkan kreatifitas dan minat belajar siswa kelas XI SMA Muhammadiya Bima dengan menggunakan cerita rakyat bima sebagai bahan ajar pada mata pelajaran bahasa Inggris. Peningkatan kreatifitas dan minat belajar pada bahasa Inggris yang mencakup skil dan kompetensi seperti: speaking (berbicara), listening (mendengarkan), reading (membaca), dan writing (menulis). Serta menggembangkan kreatifitas dan minat belajar siswa dalam memahami vocabulary (kosa kata), dan struktur kalimat. Metode yang digunakan dalam penelitian ini adalah pre-eksperimen dengan menggunakan desain one pretest-posttest. Sampel yang digunakan dalam penelitian ini adalah siswa kelas XI SMA Muhammadiyah Bima berjumlah 22 orang yang terdiri dari satu kelas. Sebelum menggunakan cerita rakyat sebagai bahan ajar akan dilaksanakan tes untuk mengetahui kemampuan awal siswa (pretest) terkait dengan skil dan kompetensi siswa, sedangkan kreatifitas dan minat belajar di nilai dengan menggunakan lembar observasi yang kemudian hasilnya dipersentasikan. Hasil yang diperoleh pada penelitian ini adalah terjadi peningkatan terhadap kreatifitas dan minat belajar siswa setelah diberikan treatmen atau pembelajaran bahasa Inggris dengan menggunakan cerita rakyat bima sebagai bahan ajar. Peningkatan tersebut ditunjukkan dari perolehan hasil skor dengan nilai rata-rata sebesar 46,72, sedangkan pada post test sebesar 52,95.
\end{abstract}

Kata Kunci: kreatifitas siswa, minat belajar, cerita rakyat Bima.

\section{PENDAHULUAN}

Mata pelajaran Bahasa Inggris adalah salah satu mata pelajaran yang wajib dikuasai oleh siswa untuk menjawab tantangan perkembangan zaman yang semakin modern, terbuka, dan global. Sehingga, pendidik atau guru perlu memikirkan cara-cara menarik untuk membuat siswa dapat menguasai bahasa Inggris sama dengan mereka menguasai bahasa lokal atau bahasa daerah mereka sendiri. Namun, tidak hanya pada ranah kognitif dan psikomotor saja yang perlu dipikirkan, tapi juga pada ranah afektif seperti kreatifitas dan minat belajar siswa juga perlu menjadi pertimbangan untuk ditingkatkan agar potensi diri siswa dapat berkembang dengan maksimal.

Kreatifitas dan minat belajar merupakan dua komponen dalam ranah afektif yang harus dimiliki dan ditingkatkan pada peserta didik. Menurut Untary, Erny (2016) Kreatifitas merupakan "kekayaan pribadi" yang diwujudkan dalam sikap atau karakter, seperti fleksibel, terbuka, keinginan mencoba sesuatu, keteguhan, serta kemampuan menjabarkan gagasan dan kemampuan mengenal diri sendiri secara realistis. Kreatifitas akan menghasilkan pembelajaran yang efektif yang dapat menggembangkan nalar peserta didik, hal ini tentu dapat digunakan untuk mengatasi persoalan dalam pembelajaran.

Peningkatan dan penggembangan potensi kreatif siswa akan menghasilkan superior learning. Wisnawati (2014) menyatakan bahwa siswa yang memiliki kemampuan berpikir kreatif akan memiliki motivasi intrinsik yang tinggi dalam belajar, dan memiliki daya dorong yang kuat, percaya diri, dan kemampuan berpikir tinggi. Dengan kata lain, menurut wilda, salwah, shindy (2016) kreatifitas memberikan kemampuan yang diperlukan untuk menghadapi kehidupan mendatang yang tidak menentu.

Sehingga, berpikir kreatif merupakan unsur penting untuk mewujudkan pembelajaran yang berhasil atau pendidikan bermutu dan keberhasilan dalam kehidupan. Menurut Fitri Ningsih, Supriadin, Nurhidayah (2019) beberapa 
ciri- ciri kepribadian kreatif antara lain memiliki rasa ingin tahu yang luas dan mendalam, sering mengajukan pertanyaan dengan baik dan benar, memberikan banyak ide dan gagasan atau usulan terhadap suatu persoalan, bebas dalam menyatakan pendapat, mempunyai rasa keindahan yang luas dan dalam, unggul dalam salah satu bidang, mampu melihat persoalan dari berbagai/segi sudut pandang yang berbeda, mempunyai rasa humor yang tinggi, memiliki daya imajinasi, dan orisinal dalam ungkapan gagasan dan dalam pemecahan berbagai masalah.

Sedangkan minat belajar menjadi salah satu indikator keberhasilan dalam proses belajar dan mengajar di kelas. Hal ini sejalan dengan pendapat Wilda, Salwah, Shindy (2016) yang menyatakan bahwa minat belajar adalah suatu ketertarikan terhadap suatu pelajaran yang kemudian mendorong individu untuk mempelajari dan menekuni pelajaran tersebut.

Setiap orang memiliki minat belajar yang berbeda-beda, sehingga untuk mengukurnya terdapat indikator sebagaimana yang dinyatakan oleh Djamarah (2011) bahwa Indikator untuk mengetahui minat seseorang dalam belajar adalah: (a) adanya pemusatan perhatian, perasaan dan pikiran terhadap pembelajaran karena adanya ketertarikan, (b) adanya perasaan senang terhadap pembelajaran, (c) adanya kemauan atau kecenderungan pada diri subyek untuk terlibat aktif dalam pembelajaran serta untuk mendapat hasil yang terbaik.

Dalam upaya meningkatkan kreatifitas dan minat belajar siswa pada mata pelajaran bahasa Inggris maka sangat perlu dilakukan inovasi, salah satunya adalah dengan menggunakan cerita rakyat sebagai bahan ajar. Peningkatan kreatifitas dan minat belajar siswa diasumsikan akan dapat juga meningkatkan kemampuan siswa dalam menguasai skil dan kompetensi yang ada dalam bahasa Inggris.

Menurut Nunung Fatimah (2017) cerita rakyat merupakan warisan budaya nasional dan memiliki nilai dan pesan moral yang dapat dikembangkan dan dimanfaatkan untuk mengedukasi peserta didik. Cerita rakyat juga telah lama lahir sebagai wahana pemahaman dan gagasan serta pewarisan tata nilai yang tumbuh dalam masyarakat. Bahkan cerita rakyat telah berabad-abad berperan sebagai dasar komunikasi antara pencipta dan masyarakat, dalam arti ciptaan yang berdasarkan lisan dan lebih mudah diganti karena ada unsur yang dikenal masyarakat.

Berdasarkan pernyataan tersebut dapat disimpulkan bahwa cerita rakyat merupakan bagian yang tidak asing di masyarakat begitupun ketika cerita rakyat tersebut dijadikan sebagai bahan ajar disekolah yang diharapkan akan meningkatkan kreatifitas dan minat belajar siswa, juga memberikan dampak positif terhadap karakter dan nilai moral siswa. Penggunaan cerita rakyat sebagai bahan ajar juga merupakan bagian yang tak terpisahkan dari usaha untuk melestarikan budaya dan memperkenalkan kembali budaya tersebut dikalangan siswa karena mengandung banyak pesan moral dan kearifan karakteristik masyarakat lokal.

Desain bahan ajar dengan menggunakan cerita rakyat lokal yang ada di Kabupaten dan Kota Bima dapat memberikan gambaran kepada siswa secara lebih kontekstual dan autentik sehingga mudah di pahami oleh siswa dan dapat membantu menggembangkan kreatifitas siswa dan pembelajaran Bahasa Inggris.

Berdasarkan uraian latar belakang masalah diatas maka tujuan dari penelitian ini adalah untuk meningkatkan kreatifitas dan minat belajar siswa pada mata pelajaran Bahasa Inggris dengan menggunakan cerita rakyat Bima.

\section{METODE PENELITIAN}

Penelitian ini menggunakan metode preeksperimental one group pretest-posttest. Sampel penelitian terdiri dari satu kelas yaitu kelas XI SMA Muhammadiyah yang berjumlah 22 orang. Sebelum diberikan perlakuan, dilakukan Pretest untuk mengukur kreatifitas, minat belajar dan kemanpuan awal siswa pada mata pelajaran Bahasa Inggris yang meliputi 4 skill (listening. Speaking, reading and writing) dan 2 komptensi (structure and vocabulary), kemudian diberikan perlakuan atau treatment dengan menggunakan bahan ajar yang dirancang dengan menggunakan cerita rakyat Bima, setelah itu dilakukan posttest untuk mengukur peningkatan kreatifitas dan minat belajar serta kemampuan siswa pada mata pelajaran bahasa 
Inggris. Adapun langkah-langkah pelaksanaan penelitian sebagai berikut:

1. Tahap persiapan: a) observasi awal, wawancara dengan guru dan siswa terkait kreatifitas dan minat belajar siswa, b) menyusun instrument pembelajaran seperti silabus, RPP, lembar kegiatan siswa, kisikisi soal, soal pre dan post test, c) melakukan validasi instrument dengan ahli, d) melakukan uji coba instrument yang telah dibuat, e) menganalisis hasil uji coba instrument untuk mengetahui validitas dan reliabilitas instrument.

2. Tahap pelaksanaan: a) melakukan pre-test, b) memberikan treatmen dengan menggunakan cerita rakyat Bima sebagai bahan ajar, c) melakukan observasi selama pembelajaran berlangsung, d) memberikan post-test untuk mengetahui peningkatan kreatifitas dan minat belajar siswa terhadap mata pelajaran Bahasa Inggris.

3. tahap akhir: a) mengolah data hasil pretestposttest, dan istrumen lainnya, b) membandingkan hasil analisis data sebelum diberikan perlakuan dengan setelah diberikan perlakuan, c) memberikan kesimpulan dan saran berdasarkan hasil yang diperoleh dari penelitian.

\section{HASIL DAN PEMBAHASAN}

Tujuan dari penelitian ini adalah untuk meningkatkan kreatifitas dan minat belajar siswa dengan menggunakan cerita rakyat Bima. Pada table 1 adalah deskripsi data pre test yang dilakukan oleh siswa.

Tabel 1. Deskripsi data pre-test siswa

\begin{tabular}{|l|l|}
\hline Deskripsi & Pre-test \\
\hline Nilai Minimum & 36 \\
\hline Nilai Maksimum & 76 \\
\hline Range & 40 \\
\hline Rata-rata & 46.72 \\
\hline Standar Deviasi & 26,12 \\
\hline
\end{tabular}

Berdasarkan tabel 1. Hasil pre-test yang telah dilakukan pada siswa SMA Muhammadiyah Bima kelas XI MIA yang berjumlah 22 orang, dengan menggunakan soal jenis subjective test atau soal uraian yang berjumlah 10 nomor, didapatkan nilai atau skor minimum yang diperoleh siswa adalah 36, range atau rentang nilai 40, sedangkan skor maksimun yang diperoleh adalah 76 , dengan nilai rata-rata yang diperoleh secara keseluruhan adalah 46,72, dan standar deviasi 26,12.

Sedangkan hasil post test yang diperoleh oleh siswa terdapat pada table 2 berikut:

Tabel 2. Deskripsi hasil post test siswa

\begin{tabular}{|l|l|}
\hline Deskripsi & Post-test \\
\hline Nilai Minimum & 42 \\
\hline Nilai Maksimum & 77 \\
\hline Range & 35 \\
\hline Rata-rata & 52.95 \\
\hline Standar Deviasi & 19.98 \\
\hline
\end{tabular}

Berdasarkan table 2 deskripsi hasil post test siswa diperoleh nilai atau skor minimum adalah 42 , nilai atau skor maksimum adalah 77 , range atau rentang nilai 35 , nilai rata-rata 52.95 , dan standar deviasi 19.98.

Secara keseluruhan berdasarkan deskripsi data pre dan post test dapat disimpulkan terdapat peningkatan kreatifitas dan minat belajar pada siswa SMA Muhammadiyah Bima kelas XI MIA dengan menggunakan cerita rakyat Bima sebagai bahan ajar.

Hal ini juga didukung oleh hasil observasi terhadap kreatifitas dan minat belajar siswa selama pembelajaran dengan menggunakan cerita rakyat Bima, sebagaimana tertera dalam table 3.

Deskripsi hasil observasi kreatifitas siswa berdasarkan indikator

\begin{tabular}{|l|l|l|l|}
\hline No & $\begin{array}{l}\text { Ciri-Ciri } \\
\text { Kreatifitas pada } \\
\text { siswa }\end{array}$ & $\begin{array}{l}\text { Indikator } \\
\begin{array}{l}\text { Memiliki rasa } \\
\text { ingin tahu yang } \\
\text { besar }\end{array}\end{array}$ & $\begin{array}{l}\text { Persen } \\
\text { tase } \\
\text { hasil }\end{array}$ \\
\hline 1 & $\begin{array}{l}\text { siswa } \\
\text { memperhati } \\
\text { kenjelasan } \\
\text { guru } \\
\text { mengajukan } \\
\text { pertanyaan yang } \\
\text { berbobot }\end{array}$ & $\begin{array}{l}\text { Siswa } \\
\text { mengajukan } \\
\text { pertanyaan } \\
\text { terkait } \\
\text { materi cerita } \\
\text { rakyat Bima } \\
\text { yang }\end{array}$ & $80 \%$ \\
\hline
\end{tabular}


terakreditasi Peringkat 4 (No. SK: 36/E/KPT/2019)

\begin{tabular}{|c|c|c|c|}
\hline & & $\begin{array}{l}\text { dijelaskan } \\
\text { oleh guru }\end{array}$ & \\
\hline 3 & $\begin{array}{l}\text { Memberikan } \\
\text { banyak gagasan } \\
\text { dan usul }\end{array}$ & $\begin{array}{l}\text { Siswa } \\
\text { meberikan } \\
\text { saran dan } \\
\text { ide pada saat } \\
\text { diskusi atau } \\
\text { pembelajara } \\
\text { n dengan } \\
\text { materi } \\
\text { menggunak } \\
\text { an cerita } \\
\text { rakyat Bima } \\
\text { berlangsung }\end{array}$ & $58,4 \%$ \\
\hline 4 & $\begin{array}{l}\text { Mampu } \\
\text { menyatakan } \\
\text { pendapat spontan } \\
\text { dan tidak malu- } \\
\text { malu }\end{array}$ & $\begin{array}{l}\text { Siswa } \\
\text { menyatakan } \\
\text { pendapat } \\
\text { atas } \\
\text { penjelasan } \\
\text { atau } \\
\text { jawaban } \\
\text { yang } \\
\text { diberikan } \\
\text { oleh guru } \\
\text { atau teman } \\
\text { kelas } \\
\text { lainnya } \\
\text { selama } \\
\text { pembelajara } \\
\text { n } \\
\text { berlangsung }\end{array}$ & $90 \%$ \\
\hline 5 & $\begin{array}{l}\text { Memiliki rasa } \\
\text { keindahan }\end{array}$ & $\begin{array}{l}\text { Siswa } \\
\text { mampu } \\
\text { mengemuka } \\
\text { kan secara } \\
\text { verbal atau } \\
\text { tulisan nilai- } \\
\text { nilai yang } \\
\text { terkandung } \\
\text { dalam cerita } \\
\text { rakyat }\end{array}$ & $83,4 \%$ \\
\hline 6 & $\begin{array}{l}\text { Mempunyai } \\
\text { pendapat sendiri } \\
\text { dan tidak mudah } \\
\text { terpengaruh oleh } \\
\text { orang lain }\end{array}$ & $\begin{array}{l}\text { Siswa } \\
\text { memiliki } \\
\text { pendapat } \\
\text { atau } \\
\text { pandangan } \\
\text { sindiri } \\
\text { ketika } \\
\text { berdiskusi } \\
\text { atau }\end{array}$ & $80 \%$ \\
\hline
\end{tabular}

\begin{tabular}{|c|c|c|c|}
\hline & & $\begin{array}{l}\text { pembelajara } \\
\text { n dengan } \\
\text { cerita rakyat } \\
\text { Bima } \\
\text { berlangsung } \\
\text { dan tidak } \\
\text { mudah } \\
\text { dipengaruhi } \\
\text { oleh } \\
\text { pendapat } \\
\text { atau } \\
\text { pandangan } \\
\text { orang lain, } \\
\text { tetap yakin } \\
\text { terhadap } \\
\text { jawaban dari } \\
\text { soal atau } \\
\text { tugas yang } \\
\text { telah } \\
\text { dikerjakan } \\
\text { meskipun } \\
\text { banyak } \\
\text { kritikan dari } \\
\text { orang lain }\end{array}$ & \\
\hline 7 & $\begin{array}{l}\text { Memiliki rasa } \\
\text { humor yang } \\
\text { tinggi }\end{array}$ & $\begin{array}{l}\text { Siswa } \\
\text { mengikuti } \\
\text { pembelajara } \\
\text { n dengan } \\
\text { santai, }\end{array}$ & $76,7 \%$ \\
\hline 8 & $\begin{array}{l}\text { Mempunyai daya } \\
\text { imajinasi kuat }\end{array}$ & $\begin{array}{l}\text { Siswa } \\
\text { menjawab } \\
\text { atau } \\
\text { menyelesaik } \\
\text { an soal } \\
\text { dengan cara } \\
\text { yang } \\
\text { berbeda dari } \\
\text { yang } \\
\text { dicontohkan } \\
\text { sesuai } \\
\text { dengan } \\
\text { imajinasiny } \\
\text { a, } \\
\text { Mudah } \\
\text { melihat } \\
\text { kekurang } \\
\text { sempurnaan } \\
\text { suatu penyelesaia } \\
\text { n atau }\end{array}$ & $73,3 \%$ \\
\hline
\end{tabular}


terakreditasi Peringkat 4 (No. SK: 36/E/KPT/2019)

\begin{tabular}{|c|c|c|c|}
\hline & & $\begin{array}{l}\text { jawaban } \\
\text { soal }\end{array}$ & \\
\hline 9 & $\begin{array}{lr}\text { Mampu } & \\
\text { mengajukan } & \\
\text { pemikiran } & \text { dan } \\
\text { gagasan } & \text { yang } \\
\text { berbeda } & \text { dari } \\
\text { orang } & \text { lain } \\
\text { (orisinal) } & \end{array}$ & $\begin{array}{l}\text { Siswa dapat } \\
\text { menjawab } \\
\text { soal atau } \\
\text { tugas secara } \\
\text { verbal atau } \\
\text { tertulis yang } \\
\text { berbeda } \\
\text { dengan } \\
\text { siswa } \\
\text { lainnya }\end{array}$ & $66,7 \%$ \\
\hline 10 & $\begin{array}{l}\text { Dapat bekerja } \\
\text { sendiri }\end{array}$ & $\begin{array}{l}\text { Siswa dapat } \\
\text { menyelesaik } \\
\text { an soal atau } \\
\text { tugas yang } \\
\text { diberikan } \\
\text { secara } \\
\text { individu } \\
\text { tanpa } \\
\text { bantuan dari } \\
\text { orang lain }\end{array}$ & $74,4 \%$ \\
\hline 11 & $\begin{array}{l}\text { Senang mencoba } \\
\text { hal-hal baru }\end{array}$ & $\begin{array}{l}\text { Siswa berani } \\
\text { menerima } \\
\text { tugas-tugas } \\
\text { yang sulit, } \\
\text { siswa } \\
\text { antusias } \\
\text { dengan } \\
\text { informasi } \\
\text { baru }\end{array}$ & $90 \%$ \\
\hline 12 & $\begin{array}{l}\text { Dapat } \\
\text { mengembangkan } \\
\text { suatu gagasan }\end{array}$ & $\begin{array}{l}\text { Siswa dapat } \\
\text { mengemban } \\
\text { gkan suatu } \\
\text { gagasan atau } \\
\text { ide terkait } \\
\text { dengan } \\
\text { materi } \\
\text { pembelajara } \\
\text { n yang } \\
\text { sedang } \\
\text { berlangsung }\end{array}$ & $66,7 \%$ \\
\hline
\end{tabular}

Berdasarkan hasil observasi terhadap kreatifitas siswa selama pembelajaran dengan menggunakan bahan ajar dari cerita rakyat Bima, maka diketahui bahwa ada dua ciri-ciri kreatifitas pada siswa SMA Muhammadiyah kelas XI MIA yang dominan, hal ini berdasarkan pada presentase hasil observasi yaitu sebesar $90 \%$.
Sedangkan deskripsi pada hasil observasi terhadap minat belajar siswa ditunjukkan pada table 4

Tabel 4 hasil observasi minat belajar siswa

\begin{tabular}{|l|l|l|}
\hline No & Indikator Minat Belajar & $\begin{array}{l}\text { Persentasi } \\
\text { Hasil }\end{array}$ \\
\hline 1 & $\begin{array}{l}\text { Adanya pemusatan } \\
\text { perhatian, perasaan dan } \\
\text { pikiran terhadap } \\
\text { pembelajaran karena } \\
\text { adanya ketertarikan } \\
\text { yang terlihat dari sikap } \\
\text { dan antusias siswa } \\
\text { selama pembelajaran } \\
\text { berlangsung }\end{array}$ & $83,3 \%$ \\
\hline 2 & $\begin{array}{l}\text { Adanya perasaan } \\
\text { senang terhadap } \\
\text { pembelajaran yang } \\
\text { ditunjukkan dengan } \\
\text { partisipasi selama } \\
\text { kegiatan pembelajaran } \\
\text { berlangsung }\end{array}$ & $73,3 \%$ \\
\hline 3 & $\begin{array}{l}\text { Adanya kemauan atau } \\
\text { kecenderungan pada } \\
\text { diri subyek untuk } \\
\text { terlibat aktif dalam } \\
\text { pembelajaran serta } \\
\text { untuk mendapat hasil } \\
\text { yang terbaik }\end{array}$ \\
\hline
\end{tabular}

Pada tabel 4 deskripsi persentasi hasil observasi minat belajar siswa Muhammadiyah Bima kelas XI MIA didapatkan hasil tertinggi adalah sebesar 83,3\%. Dimana, siswa menunjukkan adanya pemusatan perhatian, perasaan dan pikiran terhadap pembelajaran karena adanya ketertarikan yang terlihat dari sikap dan antusias siswa selama pembelajaran berlangsung.

\section{KESIMPULAN}

Penggunaan cerita rakyat Bima dapat meningkatkan kreatifitas dan minat belajar siswa pada mata pelajaran Bahasa Inggris. Cerita rakyat Bima yang digunakan juga memberikan dampak positif lainnya selain peningkatan pada kreatifitas dan minat belajar, tapi juga pada kemauan siswa untuk lebih mengenal cerita 
rakyat daerah mereka sendiri yang ditunjukkan dengan antusias siswa setiap pembelajaran berlangsung.

\section{SARAN}

Perlu dilakukan penggembangan bahan ajar dengan menggunakan cerita rakyat Bima sehingga aplikasinya dalam pembelajaran dapat dioptimalkan, terdapat banyak cerita rakyat Bima yang tersebar dimasyarakat, maka pemilihan cerita rakyat Bima yang tepat dengan nilai-nilai moral yang bisa di adopsi oleh siswa menjadi prioritas untuk dijadikan materi atau bahan ajar dikelas. Perlu dilakukan telaah mendalam sebelum mentraslate/menerjemahkan cerita rakyat Bima kedalam bahasa Inggris, karena terdapat banyak kata-kata dalam cerita Rakyat Bima yang mengacu pada makna yang bukan sebenarnya.

\section{UCAPAN TERIMA KASIH}

Terima kasih tim peneliti ucapkan kepada:

1. Kementrian Riset dan Teknologi/Badan Riset dan Inovasi Nasional

2. LLDIKTI Wilayah 8

3. STKIP Taman Siswa Bima

\section{DAFTAR PUSTAKA}

Agustinasari, susilawati E. (2018). Pemanfaatan potensi lokal dalam pembelajaran fisika untuk meningkatkan keterampilan berpikir kritis siswa SMA. Prosiding ISBN.

Djamarah. (2011). Psikologi belajar. Rineka Cipta. Jakarta

Fitri Ningsi, Supriadin, Nurhidayah. (2019). Peningkatan kreatifitas dan self efficacy mahasiswa pada mata kuliah writing IV melalui pembelajaran generative berbasis masalah terbuka. Prosiding ISBN

Machmuda Ayu. (2013). Penggembangan bahan ajar membaca cerita anak berbasis cerita rakyat Jawa Timur untuk siswa kelas V MI Nurul Huda Mulyorejo Malang. Skripsi. UIN Maulana Malik Ibrahim Malang.

Nunung Fatimah. (2017). Penggembangan buku cerita rakyat Bima berbasis kearifan local. Jurnal NOSI Volume 5, nomor 3, 267-268.

Syarifah, Intan. (2019). Pengembangan instrument penilaian untuk mengukur kreatifitas siswa dalam menyelesaikan masalah matematika. Skripsi. UIN Sunan Ampel Surabaya.

Untary, Erny. (2016). Pengaruh kreatifitas dan minat belajar mahasiswa. Skripsi. Pdf

Wildah, Salwah, Shindy. (2016). Pengaruh kreatifitas dan minat belajar terhadap hasil belajar matematika siswa. Jurnal. Vol 2, Nomor 1. Diunduh dari journal.uncp.ac.id

Wisnawati. (2014). Pengaruh konsep diri dan motivasi belajar terhadap hasil belajar siswa kelas XI IPA Negeri I Malili. Skripsi. FKIP-UNCP. Palopo. 